\title{
The System in Islamic Banking In-terms of Customer Satisfaction in Pakistan
}

\author{
Syed Muhammad Kazim Hamdani \\ Researcher \\ Foundation University Rawalpindi Campus,NewLalazar, Rawalpindi, Pakistan.
}

\begin{abstract}
Customer satisfaction is one of the most important aspects of banking sector. The satisfaction of different customers in Pakistan is very much focused on receiving good quality of products and level of customer services provided by the employees in the Islamic banks. The research objective was to check the customer satisfaction of different users and how they accept the Islamic banking. The research was conducted through questionnaire survey, Meezan and Bank Islami were considered for the collection of data. The section of research includes 149 different customers from Bank Islami and Meezan bank. Regression. Anova and correlation were used and it shows a positive relationship. The study helps the employees to grow themselves as well as to increase their standing and to carry variation about the products/services as compared to the other banking system.
\end{abstract}

\section{Introduction:}

It has become a global and much generalized concept that the term RIBA actually describes the word "interest" as a complete theory. Literally RIBA is defined as "an increase" commonly known as "usury'. From an Islamic point of view, usury is considered an illegal act in SHARIA, because it stands for an increase in a forbidden manner. However, two broad projections are usually found associated with the term usury. The first suggest the lending notion whereas the second one suggests the Trading. Trading includes the currency and commodities trading that follow special stipulation. Here, modern banking support and practice both these types of usury.

When this interest based classification is compared to the operations of Islamic banking, it presents a system mainly divided into three main categories.

- AL- MUSHARAKAH

- ALMURABEHAH

- AL- MUDARABAH

\section{Musharaka\&Modaraba}

Musharaka or Shirkahare also known as Partnership. It specifies a business based on partnership where monetary investments are made by all the associates.Other form of partnership is known as Modaraba. Under this category, any or few associates in a business remain inactive in all the business doings and implementations. Modern time also term this resting partnership as dormant partnership.

Modaraba id divided in the following two categories:

- Modaraba Al-Muqayyaddah: this is also known as Restricted Modaraba: under this type, the reason of Modaraba is explicitly stated and compiled with.

- Modaraba Al-Mutlaqah: Also known as unrestricted Modaraba; under this type, Modarib has the liberty to opt and commence the business according to his aspiration.

Modaraba planning offers maximum profit to both the associates, i-e. The Rab-ul-Mal and the Modarib. It facilitates the Rab-ul-Mal to consume his capital and the Modarib to use his entrepreneurship and proficiency whereas the profit and loss allocation system stands on the rule of judgment and impartiality.

Musharaka means sharing. In the Islamic form of financing, Muskaraka is quite a common type of finance. In an Islamic financing organization, this style is used as a first preference based on the accountability conduct.

Over the last few years, Islamic banking industry has been in the effort to expand its exceed and to be at the point where conventional banking stands, but here the problem is lack of legal framework due to nonexistence of sharia which can make interest free banking a tolerable scheme, and thus become a main obstacle behind its little diffusion in the financial market. Endeavors should make to alter the existing configuration to offer a better quality services within the domain of Islamic commandments.

Banks in Pakistan are not only trapped in exceedingly competitive domestic challenge but also encounter inter global place to accomplish a remarkable slot in Asian region. To foster the customer attention in a progressive market, a good amount of money is being used in an incorrect manner. 
In this new era, business is all about the name and identity, its maximized appearance on global e-economic podium, quick visibility on search engines. Also the pleasant names and easy memorability are additional benefits to run a business successfully.

The banking reforms started in 1990s, have changed the zone into proficient and powerful banking systems. The complete evaluation carried out mutually by the World Bank and IMF in 2004 put the following concluding documentation.

Some outreached modifications have resulted in further competent financial system. The legislative framework and the state bank of Pakistan administrative capacity have become better significantly and as a result the financial sector exhibits increase pliability to stocks.

Islamic banking is based on Islamic SHARIA and Islamic law that strictly forbid Riba(interest). Therefore all business transactions must be based on justice and equity and exploitation of any manner is strictly forbidden. Three modes Musharikah, Modarbah and Qarz e Hasna are in agreement with Sharia law. There are several areas of dissatisfaction with the Islamic banks such as the depositors are not getting adequate on their banks deposits that need to be addressed. The regain the depositors confidence it is need of the day to assess some fundamental problems to meet the Islamization process a success.

\section{Problem statement:}

The background of the problem that leads to the problem statement i.e. the level of satisfaction of customers towards the Islamic banking system in Pakistan?

\section{Originality of the study:}

The study which is going to be conducted that The satisfaction of different clients with the reference of banking in the Islamic tactic.

\section{Applied aspects:}

The customer image and the customer trust is the focus which is how customers react to the structure of banks and whether customers acquire desired satisfaction.

\section{Research question:}

The overall aim of this study is to understand customer's approach toward Islamic Banking practice in Pakistan. In order to succeed this overall aim of the study, this objective is to be fulfilled.

- To identify the perception of general people of Pakistan toward recent Islamic Banking practice in Pakistan through questionnaire survey.

\section{Hypothesis}

H1: Satisfaction is surely connected to bank's image

H2: Loyalty/satisfaction of customers should interlink with each other completely.

\section{Literature Review}

In the banking industry satisfaction of different customers are to be judged so that proper and preferred products and services are to be offered to the clients because clients are crucial cause of one's revenue.

The consumers with the longer period of time are beneficiary rather than the customers having their account for a shorter time. Liang and wang (2004)

While making transactions mostly clients of banks choose on spot communication with the employees. So that employees are extremely educated and skilled to meet the needs of the users. Loriene (2003)

New consumers are tried to be provided with the interested services/products and making sure not to misplaced the current ones. Rose\&Morquis (2006)

Banks are not only to compete each other but they have to compete with non-bank financial institutions. Wel\&Nor (2003), the convenience of location is also motivating factor for customer. Kenning ton etal (1996) \&Almossawi (2001), viewed bank's reputation the most significant factor.Gerord\& Cunning (2001) feeling secure for most customer is important for selecting a bank. Cohen,Gen,Young\&Choong (2006)

In their opinion, profitability factor acertain bank is picked by the customer having little charges and more rental fees. Taald Gar (2000) \&Kaynak\&Harcar (2005)

According to Islamic system they have not sufficient knowledge. Kotler (1988); McIver \& Naylor (1986), Engel, Blackwell,\&Miniard (1993) that having reasonable edge it is very important to accept clients interest and actions. Metawa\&Almossawi (1998)

There is a substantial difference that is the closure of 'Riba' in monetary dealings. Commercial transactions and some events are redirected to banking of Islamic banks with reverence to the release of holy and group duties. The core vision of the banks is that their banking should base on the revenue and loss rule. The properties which 
are having not as much of FIVE percentage are surely established on earning and cost of Islamic system. Dusuki(2007)

\section{THEORITICAL FRAMEWORK:}

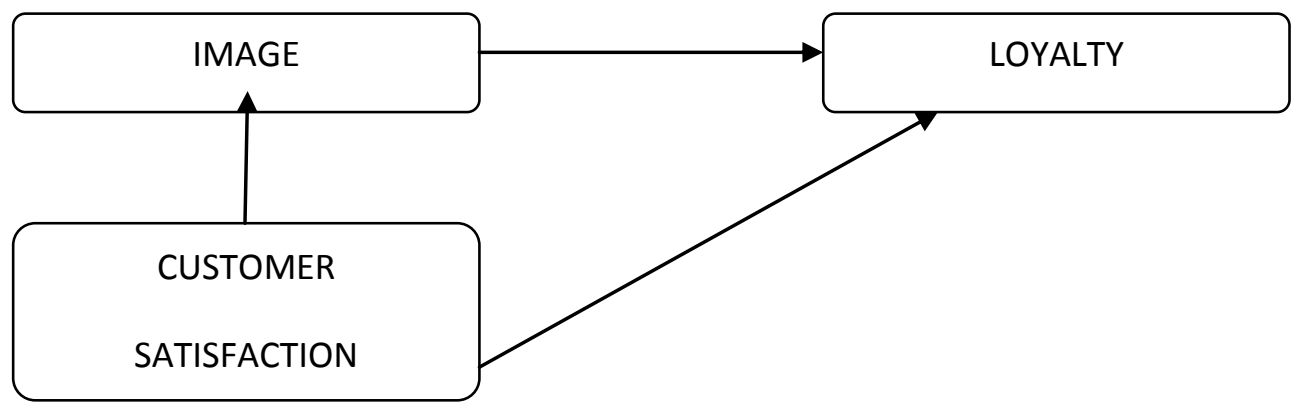

IV. Methodology:

Task covers 149 users from Meezan and Bank Islami and their different perceptions are to be checked.

Data collection:

A scale of standardization customer satisfaction is taken to have results. Likert scale is used to find the outcome of customer satisfaction towards Islamic banking. The questionnaire was self-developed and it was open ended.

\section{Selection criteria:}

The consumers of separate banks are asked. The main part of the study was to collect personal information from the different customers. Different customers were chosen for the study. For this customers of Meezan bank and Bank Islami were taken.

A Grand total of 149 customers

\section{BANK ISLAMI}

75 customers

\section{MEEZAN BANK \\ 74 customers}

Correlations

\begin{tabular}{|l|l|l|l|l|}
\hline \multicolumn{2}{|l|}{ Correlations } & Customer Image & $\begin{array}{l}\text { Customer } \\
\text { Loyalty }\end{array}$ & $\begin{array}{l}\text { Customer } \\
\text { Satisfaction }\end{array}$ \\
\hline \multirow{3}{*}{ Customer Image } & Pearson Correlation & 1 & $.524^{* *}$ & $.470^{* *}$ \\
\cline { 2 - 5 } & Sig. (2-tailed) & & .000 & .000 \\
\cline { 2 - 5 } & $\mathrm{N}$ & 149 & 149 & 149 \\
\hline \multirow{3}{*}{ Customer Loyalty } & Pearson Correlation & $.524^{* * *}$ & 1 & $.404^{* *}$ \\
\cline { 2 - 5 } & Sig. (2-tailed) & .000 & & .000 \\
\cline { 2 - 5 } & $\mathrm{N}$ & 149 & 149 & 149 \\
\hline \multirow{3}{*}{ Customer Satisfaction } & Pearson Correlation & $.470^{* *}$ & $.404^{* *}$ & 1 \\
\cline { 2 - 5 } & Sig. (2-tailed) & .000 & .000 & 149 \\
\cline { 2 - 5 } & $\mathrm{N}$ & 149 & 149 & \\
\hline$* *$ Correlation is significant at the 0.01 level (2-tailed). & \multicolumn{2}{|l}{} \\
\hline
\end{tabular}

The process of correlation is based on the two main variables i-e dependent and independent variables. Both of these variables play an important role for the conduction of the study. The researcher mainly focuses is on the effect of customer satisfaction towards Islamic Banking of Pakistan. Here the role of the customer satisfaction is dependent variable and the other two one is independent variables. Hypothesis one is about the customer image is positively interlinked with customer satisfaction towards the Islamic bank of Pakistan. Correlation coefficient values shows that $.470^{* *}$, sig level .000 and the sample size $\mathrm{n}=149$, and the second main hypothesis is customer loyalty that is positively correlated towards the customer satisfaction, the values shows that correlation coefficient $.404 * *$, sig level .000 . Hence both the hypothesis supports this study.

\section{Regression}

\begin{tabular}{|c|c|c|c|c|}
\hline \multicolumn{5}{|c|}{ Model Summary } \\
\hline Model & $\mathrm{R}$ & R Square & Adjusted R Square & Std. Error of the Estimate \\
\hline 1 & $.505^{\mathrm{a}}$ & .255 & .245 & 1.21559 \\
\hline
\end{tabular}


The System In Islamic Banking In-terms Of Customer Satisfaction In Pakistan

\begin{tabular}{l}
\hline ANOVA \\
\begin{tabular}{|l|l|l|l|l|l|l|}
\hline Model & Sum of Squares & Df & Mean Square & F & Sig. \\
\hline \multirow{3}{*}{1} & Regression & 73.890 & 2 & 36.945 & 25.003 & $.000^{\mathrm{a}}$ \\
\cline { 2 - 7 } & Residual & 215.737 & 146 & 1.478 & & \\
\cline { 2 - 6 } & Total & 289.628 & 148 & & & \\
\hline
\end{tabular} \\
$\begin{array}{l}\text { a. Predictors: (Constant), Customer Loyalty, Customer Image } \\
\text { b. Dependent Variable: Customer Satisfaction }\end{array}$
\end{tabular}

The ANOVA table and model summary are interconnected with each other and are used to find out the multiple regression between the variables, $\mathrm{i}-\mathrm{e} \mathrm{R}=.505$, it $\mathrm{R}^{2}=.255$ whereas $\mathrm{F}=25.003$ is frequency, the study shows in the model that the variance supports it at the sig level $=.000$.

\begin{tabular}{|c|c|c|c|c|c|c|}
\hline \multicolumn{7}{|c|}{ Coefficients } \\
\hline \multirow{2}{*}{\multicolumn{2}{|c|}{ Model }} & \multicolumn{2}{|c|}{ Un standardized Coefficients } & \multirow{2}{*}{$\begin{array}{l}\text { Standardized } \\
\text { Coefficients } \\
\text { Beta }\end{array}$} & \multirow[t]{2}{*}{$\mathrm{T}$} & \multirow[t]{2}{*}{ Sig. } \\
\hline & & $\mathrm{B}$ & Std. Error & & & \\
\hline \multirow[t]{3}{*}{1} & (Constant) & 2.645 & .336 & & 7.862 & .000 \\
\hline & Customer Image & .267 & .063 & .357 & 4.253 & .000 \\
\hline & Customer Loyalty & .131 & .051 & -.217 & 2.585 & .000 \\
\hline
\end{tabular}

This coefficient table is divided into two major components such as un standardized coefficients and the other one is standardized coefficients, here the value of Beta plays an important role for the further research, according to the values best predicator considered is the customer loyalty or trust on the Islamic bank of Pakistan i-e (.217) at the sig level $=.000$. Hence this study support that the customer satisfaction have strong impact towards Islamic Banking of Pakistan.

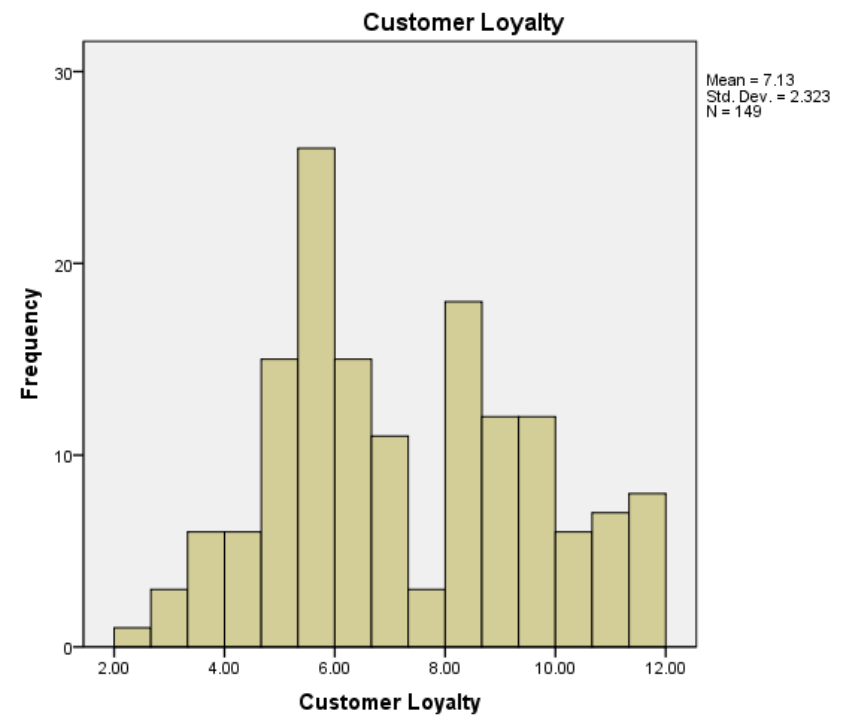

\section{Interpretation of data analysis}

Regression shows a collectively association of $\mathrm{R}=.505$ with the dependent variable customer satisfaction. $\mathrm{R}$ square .255 values shows variables described TEN percent difference in customer satisfaction. We get $\mathrm{F}$ value25.003 through ANOVA.

\section{Conclusion:}

According to this study customer satisfaction is important but several boundaries should be considered. Researchers have to recognize that how image and loyalty shows results in the model should be measured for further research. Islamic banks should have to focus on the profit offered to the customers so that customer remains with the same banks. Hence upcoming studies should contain that what are the other factors which are to be measured to improve the image of the banks that will results in the loyalty and satisfaction of the customers in the direction of the Islamic banks.

\section{Recommendation:}

Greater devotion should be paid to raise customer satisfaction that has a positive result on image, that will help bank them to sustain customer and also to build up their banking image, thus satisfaction of customers plays a major role in improving image of Islamic banks. Islamic banks should provide interest free and secure 
products/services that are confined by Islamic ethics to the customers so that it will retain customer with the bank for the long period of time.

\section{References:}

[1]. Omar Mustafa Ansari, June 19, 2007, Managing Finances: A Shariah Complaints way, Published by Time Management club, Pg number (32-40).

[2]. Hazrat Mulana Mufti Mohammad shafi, Mulana Mufti Mohammad Taqi Usmani, 1997, The Issue of Interest, $3^{\text {rd }}$ edition, Published by Dar ul Ishaat, Pg number (13-16).

[3]. S.A Meenai, 1984, Money and Banking in Pakistan, Islamization of Banking, $3^{\text {rd }}$ edition, Published by oxford university press 1984 , Pg number (50-63).

[4]. DAWN 13-05-2006 - Image building of banks.

[5]. The News 20-mar-2006 - Personal finance and consumer complaints

[6]. The News 22-05-2006 - Tougher and improved situation

[7]. The News 25-09-2006 - Interest free banking some crucial aspects

[8]. Dawn 13-19 - Islamic modes of financing, (business page-2006). 